\title{
Erratum to: The Harlan Renaissance: Colorblindness and White Domination in Justice John Marshall Harlan's Dissent in Plessy v. Ferguson
}

\author{
Phillip Hutchison ${ }^{1}$
}

Published online: 29 December 2015

(C) Springer Science+Business Media New York 2015

\section{Erratum to: J Afr Am St (2015) 19:426-447 DOI 10.1007/s12111-015-9316-y}

The original version of this paper unfortunately contained an omission. Though (Hutchison 2013) was cited in the paper, in-text citations as well as the reference details were not included.

In the references list, the below reference should be added:

Hutchison, Phillip. 2013. Race, Racism and Critical Thinking in the United States. Dubuque, IA: Kendall Hunt.

Corresponding in-text citations should appear in the following places:

Introduction section, sixth paragraph, the sentence should read: Section two responds in kind: as Harlan took pains to explicate, Jim Crow would induce one political headache after another, fueling interracial tensions domestically and tarnishing the country's reputation abroad (Hutchison 2013, p. 112).

Last sentence before the Conclusion section should read: To Harlan's lights, Jim Crow was an unnecessary factor in the calculus of white racial power; as Harlan professed it, while colorblindness would indeed condemn Jim Crow and its legally oppressive brethren, it would likewise keep whites materially dominant in perpetuity (Hutchison 2013, p. 112).

The author regrets for this oversight.

The online version of the original article can be found at http://dx.doi.org/10.1007/s12111-015-9316-y.

Phillip Hutchison

pah65047@csun.edu

1 Department of Asian American Studies, California State University, Northridge, 18111 Nordhoff Street, Northridge, CA 91330-8251, USA 